\title{
STABILITY TESTING OF AZELAIC ACID CREAM BASED ETHOSOME
}

\author{
ELSA FITRIA APRIANI ${ }^{1}$, NOVI NURLENI ${ }^{1,2}$, HERVIANTI NURFITRIA NUGRAHANI ${ }^{1}$, ISKANDARSYAH ${ }^{1 *}$
}

${ }^{1}$ Department of Pharmacy, Faculty of Pharmacy, Universitas Indonesia, Depok, Indonesia. ${ }^{2}$ Department of Pharmacy, STIFI Bhakti Pertiwi, South Sumatra, Indonesia. Email: aya_2803@yahoo.com

Received: 21 October 2017, Revised and Accepted: 30 January 2018

ABSTRACT

Objective: Azelaic acid as an antibacterial to Propionibacterium acnes bacteria in recent years began to develop as an anti-acne using lipid bilayer vesicles to increase the penetration of azelaic acid to reach sebaceous tissue which is located in the dermis of skin where the growth of bacteria P. acnes. The development of azelaic acid in lipid bilayer vesicles is also due to the absorption of azelaic acid from cream preparations by only $4 \%$. Azelaic acid gel based ethosomes also known give a larger zone of inhibition than azelaic acid creams and gels in the market.

Methods: Preparation stability test of azelaic acid cream based ethosome was chemical and physical stability. The observed physics stability was organoleptic changes, homogeneity, pH, viscosity, cycling test, and mechanical test (centrifugal test). While chemical stability was performed to know the concentration of azelaic acid in cream to be periodically. Stability test was conducted for 12 weeks and observation every 2 weeks.

Result: Physics stability test of that preparations was odorless, white, no change of phase, homogeneous, viscosity, and flow properties constant. While chemical stability test with the determination for 12 weeks to decreased content. However, these content is still included in the range of accuracy (90-110\%).

Conclusion: Azelaic acid of ethosome cream was physically and chemically stable.

Keywords: Azelaic acid, Ethosome, Cream, Stability.

(C) 2018 The Authors. Published by Innovare Academic Sciences Pvt Ltd. This is an open access article under the CC BY license (http://creativecommons. org/licenses/by/4. 0/) DOI: http://dx.doi.org/10.22159/ajpcr.2018.v11i5.23218

\section{INTRODUCTION}

It has been reported that the use of topical anti-acne is more effective than systemic; this is due to the growth of Propionibacterium acnes bacteria in the gland pilosebasea in the skin. Acne is a common disease of the pilosebaceous units of the skin, and topical therapy is recommended for the management of acne with comedolytic, antiinflammatory agents, along with antimicrobials [1]. In this study, azelaic acid used as an active ingredient because its effect of lowering the population of P. acnes and Staphylococcus epidermidis on the skin surface and pilosebasea follicles [2,3]. Azelaic acid as antibacterial to $P$ acnes bacteria in recent years began to develop as an anti-acne using lipid bilayer vesicles to increase the penetration of azelaic acid to reach sebaceous tissue which is located in the dermis of skin where the growth of bacteria P. acnes. The development of azelaic acid in lipid bilayer vesicles is also due to the absorption of azelaic acid from cream preparations by only $4 \%$ [4].

A recent study liposomal azelaic acid formulations improved bioavailability and had antibacterial and antifungal activity against Staphylococcus aureus, Pseudomonas aeruginosa, Candida albicans, and Aspergillus brasiliensis resulted that $10 \%$ azelaic acid liposomes can increase the bioavailability of azelaic acid compared with azelaic acid on the market (Skinoren 20\% $($ ) ) seen from the cumulative amount of drug release in the skin where $10 \%$ azelaic acid liposome can release the drug up to $187.5 \pm 11.3 \mathrm{mg} / \mathrm{cm}^{2}$ while Skinoren $20 \% \AA$ pass medication of $52.3 \pm 6.25 \mathrm{mg} / \mathrm{cm}^{2}$ [5]. Azelaic acid gel based ethosomes also known give a larger zone of inhibition than azelaic acid creams and gels in the market [6]. The low azelaic acid solubility of the water becomes an obstacle in the manufacture of topical formulations of azelaic acid. This study aims to reduce the concentration of azelaic acid needed to provide anti-acne effects using some formulation of etosomes to obtain an optimal and stable percentage of cream penetration.
In this research will be formulated and characterized the stability test of azelaic acid cream based ethosomes as an anti-acne. The cosmetic preparation is said to be stable when a preparation is still within acceptable limits for a period of storage time and its use, whereby its properties and characteristics are equal to those it possesses when manufactured. Cosmetic preparations are unacceptable due to physical changes, chemical changes, and changes in the content of microorganisms [7].

Physical instability of the preparation is marked by the change of color or the appearance of color, odor, changes or phase separation, the rupture of emulsions, suspension or caking precipitation, changes in consistency, crystallization, gas formation, and other physical changes [8]. Physical stability tests include organoleptic, homogeneity, $\mathrm{pH}$, viscosity, centrifugal test at low temperature, room, and high, and cycling test [9]. Chemical instability is characterized by reduced concentrations of the active substances due to chemical reactions or interactions, destruction of excipients due to hydrolysis and similar reactions, and the formation of other compounds. Chemical instability can be seen by determining the levels of active substances regularly. Active substances can be determined by several methods, in this study is used spectrophotometry UV-Vis for the determination of azelaic acid concentration in cream.

\section{MATERIALS AND METHODS}

\section{Materials}

Azelaic acid (Sigma, US), dried ethosomal suspension of azelaic acid, ethanol 96\% (Merck, Germany), Potassium dihydrogen phosphate (Merck, Germany), hydrochloric acid (Brataco, Indonesia), sodium hydroxide (Brataco, Indonesia), methanol (Merck, Germany), Dichloromethane (Merck, Germany), stearic acid (Brataco, Indonesia), cetyl alcohol (Brataco, Indonesia), isopropyl myristate (Brataco, Indonesia), triethanolamine (Brataco, Indonesia), glycerine 
monostearate (Brataco, Indonesia), propilenglicol (Brataco, Indonesia), glyserin (Brataco, Indonesia), benzoic acid (Brataco, Indonesia), butyl hydroxy toluene (Brataco, Indonesia), and aqua demineralisata (Brataco, Indonesia) are used.

\section{Preparation of azelaic acid cream based ethosome}

In this study, preparation of azelaic acid cream based ethosome refers to Iskandarsyah, Puteri and ErnySagita (2017) [10].

\section{Physical stability test}

Stability test on high, room, and low temperature

Stability preparations include organoleptic, homogeneity, $\mathrm{pH}$, and viscosity were evaluated at temperature $40 \pm 2^{\circ} \mathrm{C}, 27 \pm 2^{\circ} \mathrm{C}$, and $4 \pm 2^{\circ} \mathrm{C}$ for 12 weeks with observation every 2 weeks except for viscosity were evaluated in $27 \pm 2^{\circ} \mathrm{C}$ in 0 week and 12 weeks.

\section{Organoleptic test}

Observations organoleptic were odor, color, and the presence of phase separation in the cream.

\section{Homogeneity test}

Homogeneity test of the preparation is done to applying the cream on the glass object and then observed with microscope; preparations should be had a homogenous composition.

\section{pH measurement}

The $\mathrm{pH}$ was measured using a $\mathrm{pH}$ meter which was calibrated before use with standard buffer solutions at $\mathrm{pH} 4$ and 7 . An electrode was inserted into the azelaic acid cream based ethosome and measured the value of $\mathrm{pH}$. The average $\mathrm{pH}$ was calculated from three replicate.

\section{Viscosity test}

Viscosity of the azelaic acid cream based ethosome was determined by Brook-field Viscometer at $25^{\circ} \mathrm{C}$ using spindle 3 .

\section{Cycling test}

Cream saved at a temperature of $4^{\circ} \mathrm{C}$ for $24 \mathrm{~h}$ and then saved at a temperature of $40^{\circ} \mathrm{C}$ for $24 \mathrm{~h}$. This treatment is one cycle. The experiment was conducted with 6 cycles. The physical condition of the cream compared with previous creams, to see happen syneresis or crystallization.

\section{Centrifugal test}

Cream put in a centrifuge tube then inserted to appliance centrifugation and centrifuged at $3800 \mathrm{rpm}$ for $5 \mathrm{~h}$. Its observed whether there is a separation between oil phase and aqueous phase.

\section{Chemical stability test}

Azelaic acid content in cream

Azelaic acid cream was tested for its chemical stability by determining azelaic acid cream contained to periodically. Cream was saved for 12 weeks on three temperature conditions, at $4 \pm 2,27 \pm 2$, dnd $40 \pm 2^{\circ} \mathrm{C}$. The content of azelaic acid in the cream was determined by observation at weeks $0,4,8$, and 12 .

Specific amount of azelaic acid cream based ethosome is dissolved in methanol and then ultrasonic for $15 \mathrm{~min}$ to increase the solubility. Then, the solution was transferred to a $25 \mathrm{~mL}$ volumetric flask and dilute with phosphate buffer pH 6.8 until the volume. The content of azelaic acid was calculated by UV-vis spectrophotometer.

\section{RESULTS AND DISCUSSION}

\section{Physical stability test}

The result of organoleptic observation and homogeneity of azelaic acid cream at low temperature, room, and high can be seen in Table 1.
Based on these result indicate that during storage there is no odor change, homogeneous, and no color change. This indicates that azelaic acid cream is physically stable when stored at low, room, and high temperatures. This is also applied to the organoleptic of azelaic acid cream pictures below at low temperature, room, high, and cycling test there are no color and odor changing and phase separation (Fig. 1). There is also no crystallization or sineresis which occurs in the cycling test. This indicates that azelaic acid cream is physically stable.

The $\mathrm{pH}$ measurement data for 12 weeks can be seen in Table 1. $\mathrm{pH}$ of topical preparation should be at $\mathrm{pH}$ of skin balance (pH 4.5-6.5). Fig. 2 shown that the $\mathrm{pH}$ of azelaic acid cream in low, room, and high temperatures storage still in the $\mathrm{pH}$ range of skin balance. $\mathrm{pH}$ of the preparation should not be too acidic or alkaline because it can cause irritation to the skin. Azelaic acid cream based ethosome at low temperature, room temperature, and high temperature have lower $\mathrm{pH}$ or higher acidity. This is due to the azelaic acid detached from its matrix and ionized (negatively charged) so that the acidity increases.

The results of viscosity measurements and flow properties of ethosome azelaic acid in cream can be seen in Figs. 3 and 4. The measurement data shown that storage for 12 weeks at room temperature was decrease in viscosity at $4.08 \%$ from the week 0 of $4900 \mathrm{cps}$ to be $4700 \mathrm{cps}$ at weeks 12. The decreasing viscocity is also related to a decrease in $\mathrm{pH}$ or an increase in acidity.

Measurement of flow properties can be seen in Fig. 4. The data indicate the preparation after storage for 12 weeks does not change the flow properties and to be thixotropic plastic. From the data of viscosity and

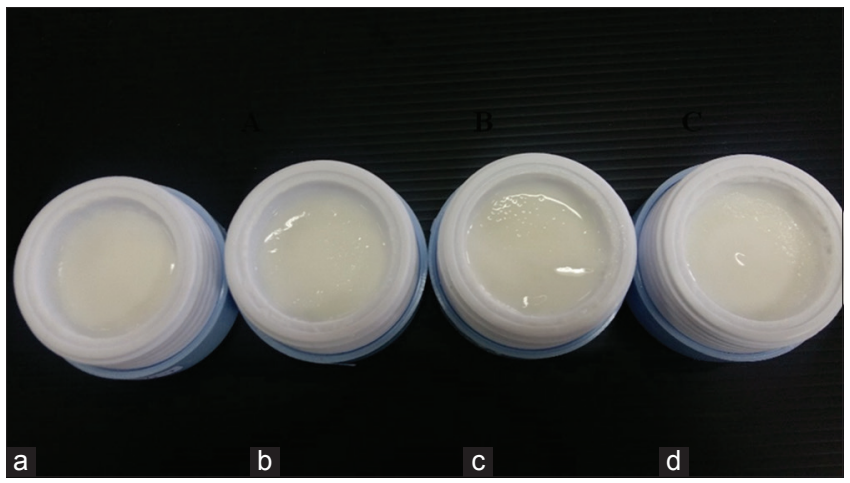

Fig. 1: Organoleptic evaluation of azelaic acid cream based ethosome. (a) Azelaic acid cream based ethosome in low temperature, (b) azelaic acid cream based ethosome in room temperature, (c) azelaic acid cream based ethosome in high temperature, and (d) azelaic acid cream based ethosome in cycling test

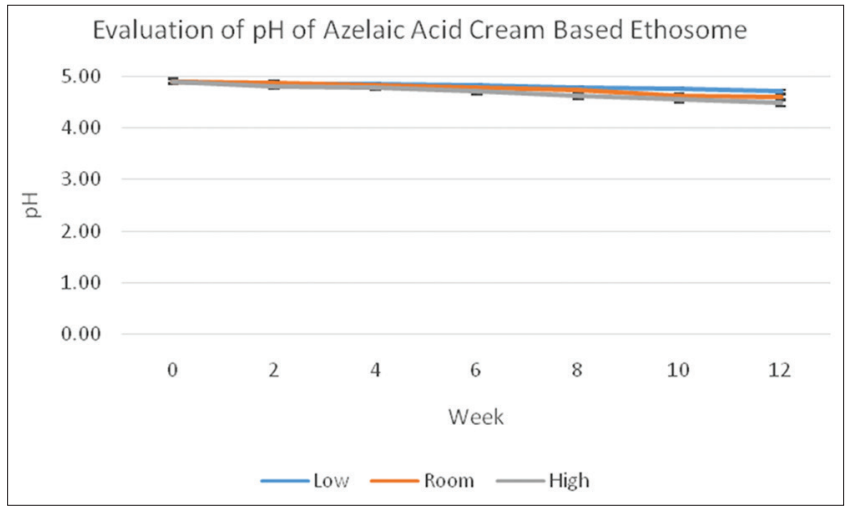

Fig. 2: pH evaluation of azelaic acid cream based ethosome in low, room, and high temperature from 0 weeks to 12 weeks 
Table 1: The result of physical stability azelaic acid cream based ethosome in low, room, and high temperature

\begin{tabular}{|c|c|c|c|c|c|c|c|}
\hline \multirow[t]{2}{*}{ Parameter } & \multicolumn{7}{|c|}{ Weeks } \\
\hline & $\mathbf{0}$ & 2 & 4 & 6 & 8 & 10 & 12 \\
\hline \multicolumn{8}{|c|}{ Low-temperature $4 \pm 2^{\circ} \mathrm{C}$} \\
\hline \multicolumn{8}{|c|}{ Organoleptic } \\
\hline Odor & No & No & No & No & No & No & No \\
\hline Color & White & White & White & White & White & White & White \\
\hline Phase separation & Good & Good & Good & Good & Good & Good & Good \\
\hline Homogeneity & Good & Good & Good & Good & Good & Good & Good \\
\hline $\mathrm{pH}$ & 4.90 & 485 & 4.84 & 4.82 & 4.78 & 4.75 & 4.70 \\
\hline \multicolumn{8}{|c|}{ Room temperature $27 \pm 2^{\circ} \mathrm{C}$} \\
\hline \multicolumn{8}{|c|}{ Organoleptic } \\
\hline Odor & No & No & No & No & No & No & No \\
\hline Color & White & White & White & White & White & White & White \\
\hline Phase separation & Good & Good & Good & Good & Good & Good & Good \\
\hline Homogeneity & Good & Good & Good & Good & Good & Good & Good \\
\hline $\mathrm{pH}$ & 4.90 & 4.86 & 4.82 & 4.77 & 4.73 & 4.61 & 4.59 \\
\hline Viscosity & 4900 & & & & & & 4700 \\
\hline \multicolumn{8}{|c|}{ High temperature $40 \pm 2^{\circ} \mathrm{C}$} \\
\hline \multicolumn{8}{|c|}{ Organoleptic } \\
\hline Odor & No & No & No & No & No & No & No \\
\hline Color & White & White & White & White & White & White & White \\
\hline Phase separation & Good & Good & Good & Good & Good & Good & Good \\
\hline Homogeneity & Good & Good & Good & Good & Good & Good & Good \\
\hline $\mathrm{pH}$ & 4.90 & 4.81 & 4.78 & 4.7 & 4.62 & 4.55 & 4.48 \\
\hline
\end{tabular}

Table 2: The content of azelaic acid in cream based ethosome

\begin{tabular}{|c|c|c|c|c|c|c|}
\hline \multirow[t]{3}{*}{ Week } & \multicolumn{6}{|c|}{ Temperature } \\
\hline & \multicolumn{2}{|l|}{ Low } & \multicolumn{2}{|l|}{ Room } & \multicolumn{2}{|l|}{ High } \\
\hline & Content (g) & Presentation(\%) & Content (g) & Presentation (\%) & Content (g) & Presentation (\%) \\
\hline 0 & 21,00 & 104,99 & 21,00 & 104,99 & 21,00 & 104,99 \\
\hline 2 & 20,61 & 103,03 & 20,90 & 104,48 & 20,23 & 101,16 \\
\hline 4 & 20,47 & 102,34 & 20,79 & 103,93 & 19,58 & 97,90 \\
\hline 6 & 20,40 & 102,02 & 20,62 & 103,09 & 19,03 & 95,16 \\
\hline 8 & 20,40 & 101,98 & 20,56 & 102,79 & 19,01 & 95,04 \\
\hline 10 & 20,39 & 101,93 & 20,53 & 102,67 & 18,91 & 94,57 \\
\hline 12 & 20,27 & 101,35 & 20,45 & 102,25 & 18,75 & 93,77 \\
\hline
\end{tabular}

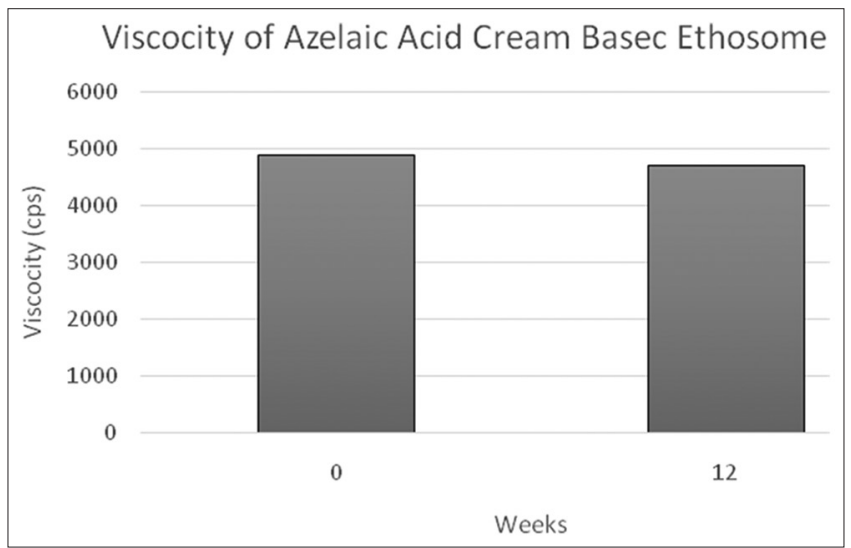

Fig. 3: Viscosity of azelaic acid cream based ethosome in room temperature at week 0 and 12

flow properties shown that there was no significant change of cream preparations so that it can be said that ethosome cream has a stable viscosity.

The mechanical observation test or centrifugal test is shown in Fig. 5 . From the figure shown that the cream preparation does not indicate the separation of the oil and water phases. This is due to the use of an emulsifier sufficient to keep the cream resistant to the given treatment (centrifugal

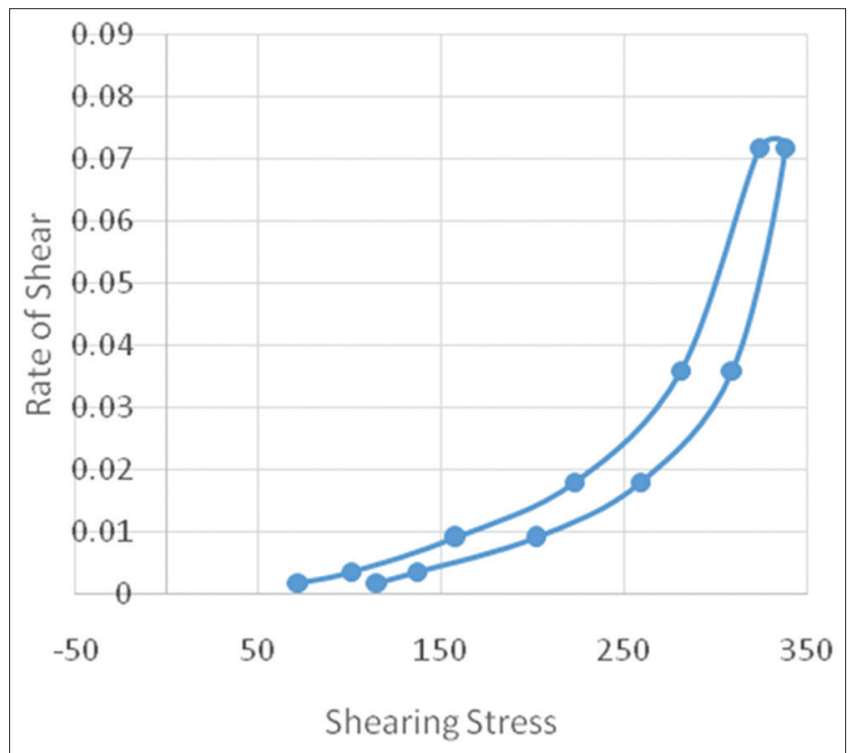

Fig. 4: Flow properties of azelaic acid cream based ethosome in room temperature

force equivalent to the force of gravity for 1 year). This suggests that the cream preparations are resistant to the effects of gravity for 1 year. 


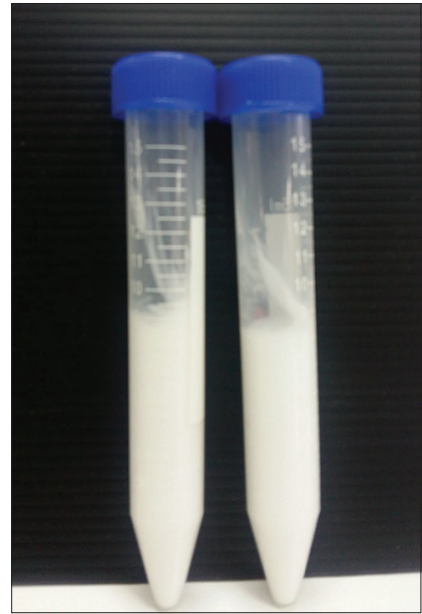

Fig. 5: Centrifugal test of azelaic acid cream based ethosome

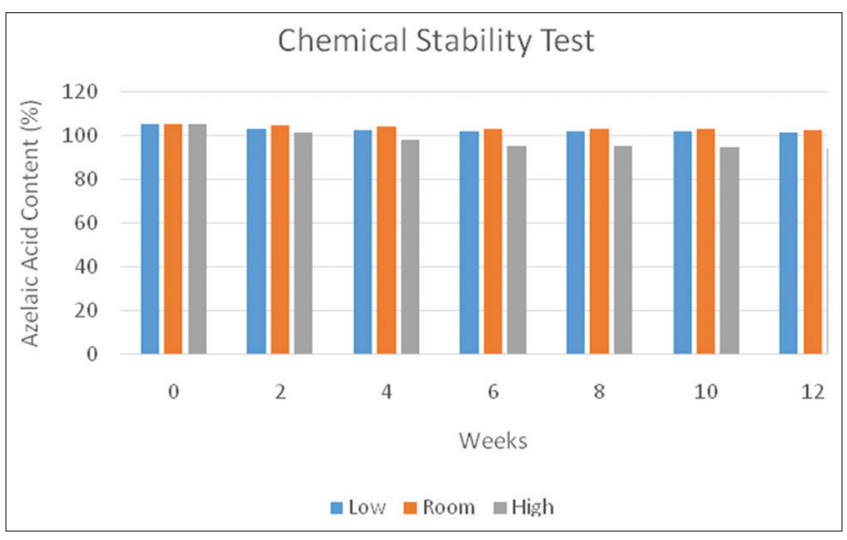

Fig. 6: Comparison of azelaic acid content in three conditions (low, room, and high temperature)

The chemical stability test of the cream preparation can be seen by determining the content of azelaic acid in the preparation at weeks $0-12$. Determination of azelaic acid content aims to determine the decrease of azelaic acid during storage with a variety of temperatures. Measurement results can be seen in Table 2 and Fig 6. From the results obtained that there is a decrease in levels in the three temperatures. There are several factors that can cause the decrease of the active substance in the dosage, such as temperature, moisture, light, solvent, ionic strength, catalyst, dielectric constant, collision theory, and transition state theory (Bu Josh). Although from the above results there is a decrease in levels in the three temperatures, still within the required range of $90-110 \%$ so it can be said that the cream preparations are chemically stable to be stored in low temperature, room, or high.

\section{CONCLUSION}

From the stability test of azelaic acid cream based ethosome, both physically and chemically, it can be concluded that azelaic acid cream based ethosome is stable physically and chemically if stored in low, room, and high temperatures.

\section{ACKNOWLEDGMENTS}

The authors would like to thank Malvern Jakarta, Nanotechnology Bogor, LIPI Bogor and Serpong, for their facilities and equipment provided. We also thank the technical staff of the Pharmaceutical Research Laboratory, Faculty of Pharmacy, University of Indonesia (Depok).

\section{AUTHOR'S CONTRIBUTIONS}

Elsa Fitria Apriani, S.Farm., Apt is a master student at the Faculty of Pharmacy, University of Indonesia. Novi Nurleni, S.Farm., Apt is a master student at the Faculty of Pharmacy, University of Indonesia. Hervianti Nurfitria Nugrahani, S.Farm., Apt is a master student at the Faculty of Pharmacy, University of Indonesia. Dr. Iskandarsyah, M.S., Apt is doctor at the Faculty of Pharmacy, University of Indonesia. He is head of Pharmaceutical Laboratory and has expertise in the development of pharmaceutical technology.

\section{REFERENCES}

1. Haris HH, Ming YK, Moon TK, Kim NS, Bum LC, Kotak V, et al. Evaluation of efficacy and safety of avco acne gel for acne: An open, single centric, non comparative study for 8 weeks. Asian J Pharm Clin Res 2012;5:73-76.

2. Nguyen QH, Bui TP. Azelaic acid: Pharmacokinetic and pharmacodynamic properties and its therapeutic role in hyperpigmentary disorders and acne. Int J Dermatol 1995;34:75-84.

3. Bojar RA, Cunliffe WJ, Holland KT. Disruption of the transmembrane $\mathrm{pH}$ gradient - A possible mechanism for the antibacterial action of azelaic acid in Propionibacterium acnes and staphylococcus epidermidis. J Antimicrob Chemother 1994;34:321-30.

4. Gollnick, H. Azelaic acid-pharmacology, toxicology and mechanisms of action on keratinization in vitro and in vivo. J Dermatol Treat 1993;4:3-7.

5. Burchacka E, Potaczek P, Paduszyński P, Karłowicz-Bodalska K, Han T, Han $\mathrm{S}$, et al. New effective azelaic acid liposomal gel formulation of enhanced pharmaceutical bioavailability. Biomed Pharmacother 2016;83:771-5.

6. Mistry A, Ravikumar P. Development and evaluation of azelaic acid based ethosomes for topical delivery for the treatment of acne. Indian J Pharm Educ Res 2016;3:50.

7. Djajadisastra J. Cosmetic Stability. Presented at "HIKI Half Day Seminar". Jakarta: SLIPI; 2004.

8. Martin A, Swarbick J, Cammarata A. Physical Pharmacy. $5^{\text {th }}$ ed., Vol. 324. Washington, Philadelpia: Lea and Febiger; 1993. p. 1083-96.

9. Kumar KK, Sasikanth K, Sabareesh M, Dorababu N. Formulation and evaluation of diacerein cream. Asian J Pharm Clin Res 2011;4:93-8.

10. Iskandarsyah I, Puteri AW, Erny Sagita E. Penetration test of caffein in ethosome and desmosome gel using an in vitro method. Int J Appl Pharm 2017;9:120-3. 